учитель англійської мови, учитель вищої категорії, старший учитель спеціалізованої школи I-III ступенів № 125 м. Києва 3 поглибленим вивченням англійської мови kolomietslarisa69@gmail.com

Городілова Тетяна Миколаївна викладач кафедри германської філології Інституту філології Київського університету імені Бориса Грінченка tatyana@okey.kiev.ua

\title{
РОЗРОБКА СЦЕНАРІЮ ПОЗАКЛАСНОГО ЗАХОДУ З АНГЛІЙСЬКОЇ ТА НІМЕЦЬКОЇ МОВ ДЛЯ УЧНІВ 8-ГО КЛАСУ НА ТЕМУ: «ЗАХИСТ НАВКОЛИШНЬОГО СЕРЕДОВИЩА: ПРОБЛЕМА ПЕРЕРОБКИ СМІТТЯ»
}

\begin{abstract}
У статті презентовано розробку позакласного заходуз німецької та англійської мов на тему: «Захист навколишнього середовища: проблема переробки сміття». Першочерговим завданням освіти є виховання цілісної та всебічно розвиненої особистості, готової реалізувати себе у суспільстві. 3 одного боку, завдяки майже безперешкодному доступу до інформаційних ресурсів учні, здавалося б, мають безліч можливостей долучитися до знань. З іншого боку, учні основноі иколи часто потребують грамотного наставництва для якісного засвоєння цієї інфрормації. Тут варто акцентувати увагу саме на фрормуванні міжпредметних зв'язків, що дає можливість учням здобути не лише практичні навички з різних галузей знання, а й закладає підгрунтя формування наукового світогляду.
\end{abstract}

Ключові слова: міжпредметні зв'язки, іншомовні компетенції, лексична компетентність, практичні навички, білінгвальне мислення.

Коломиец Лариса Петровна, учитель английского языка, учитель высшей категории, старший учитель специализированной школы I-III ступеней № 125 г. Киева с углубленным изучением иностранного языка kolomietslarisa69@gmail.com

Городилова Татьяна Николаевна, преподаватель кафедры германской филологии Института филологии Киевского университета имени Бориса Гринченко tatyana@okey.kiev.ua

Разработка сценария внеклассного мероприятия по английскому и немецкому языкам для учащихся 8-го класса на тему: "Защита окружающей среды: проблема переработки мусора"

Данная статья представляет разработку внеклассного бинарного мероприятия по английскому и немецкому языкам на тему: «Защита окружающей среды: переработка мусора». Первоочередной задачей образования является воспитаний целостной и всесторонне развитой личности, готовой к самореализации в обществе. С одной стороны, благодаря свободному доступу к информационным ресурсам, школьники, казалось бы, имеют неограниченные возможности для получения знаний. С другой стороны, учащиеся основной школы часто нуждаются в грамотном наставнике для качественного усвоения всей информации. Современный учитель также использует новейшие методические разработки и инструменты для обеспечения эфрфективной подачи материала, что особенно важно в изучении иностранных языков. Следует обратить особое внимание на формирование межпредметных связей, что способствует освоению учащимися практическими навыками в различных областях знаний и создаёт базу для фрормирования научного мировоззрения. Именно с этой целью проводятся бинарные занятия.

Ключевые слова: межпредметные связи, языковые компетенции, лексическая компетентность, практические навыки, билингвальное мышление.
Kolomiets, Larysa English Teacher, Senior Teacher of Kyiv Secondary School \# 125 Specialized in English kolomietslarisa69@gmail.com

Horodilova, Tetiana of Germanic Philology Borys Grinchenko Kyiv University tatyana@okey.kiev.ua

Scenario of an extracurricular bilingual English-German lesson "Environment Protection: Rubbish Recycling"

The article presents an extracurricular bilingual lesson on the topic "Environmental Protection: Rubbish Recycling". One of the main tasks of education is upbringing of fully developed holistic personality ready to realize oneself in a society. Nowadays, tcan use the most modern methodological tools for providing effective learning. The main accent to pay attention to is to form integrated skills giving the base in forming scientific outlook. The bilingual lesson is the best source for it. Such type of a lesson was suggested to the students of the 8th form where English is the first foreign language while German is the second one. The students are involved into the process of improving language skills.

Key words: interdisciplinary links, foreign language competencies, lexical competence, practical experience, bilingual thinking.

Метою статті $\epsilon$ презентувати спосіб формування міжпредметних зв'язків на прикладі розробки позакласного заходу з іноземних мов (англійської та німецької) для учнів 8-го класу на тему: «Захист навколишнього середовища: проблема переробки сміття».

Висновки: Зазначена вікова категорія учнів володіє складним за структурою мовним та мовленнєвим матеріалом як з англійської, так і з німецької мови. На цьому етапі навчання вчитель формує в учнів як вміння ознайомлювального характеру, тобто з метою одержання основної інформації, так і вміння вивчаючого характеру з метою одержання повної інформації. Адже доречними стають завдання, які формують вибірковий пізнавальний інтерес та допитливість. Позакласні заходи з іноземних мов дають змогу розвинути в учнів критичне мислення, формувати творчий підхід до вирішення актуальних проблем, сприяють підвищенню потреби у спілкуванні 3 однокласниками, використовуючи при цьому мовні засоби двох іноземних мов. Учні мають змогу не лише значно розширити свій активний та пасивний словникові запаси 3 англійської та німецької мови, а й дізнатися про шляхи вирішення такої актуальної на сьогодні проблеми як забруднення навколишнього середовища в інших країнах. 


\section{План позакласного заходу}

Клас: 8

Тема: "Захист навколишнього середовища: проблема переробки сміття".

Місце проведення: класна кімната.

Обладнання: Інтерактивна дошка, картки з завданнями, матеріали для виготовлення постерів.

Очікувані результати:

Учні зможуть:

- розповідати про певні аспекти захисту довкілля (проблему переробки сміття) англійською та німецькою мовами;

- аргументувати свою думку з проблеми переробки сміття білінгвально (англійською та німецькою мовами);

- розуміти на слух основний зміст відеофільмів за темою «Захист навколишнього середовища: проблема переробки сміття»;

- використовувати набуті знання з проблеми переробки сміття для створення власних групових проєктів;

- розвинути білінгвальні вміння публічних виступів.

\section{I. Вступне слово вчителів англійської та німецької мов.}

Today we have an unusual meeting. And we are going to talk about our environment and what we can do to protect it. The planet Earth is our home, our precious home. An American proverb says: "We do not inherit the Earth from our ancestors; we borrow it from our children". So, it's our duty to keep it safe and clean. Many years ago people lived in harmony with their environment but now the situation is quite different. Many parts of our world are crowded and polluted. Especially waste from factories, electric power stations and heavy industry are very dangerous. That's why our planet is in danger.

Unser Planet ist voll der Schönheit, und wenn wir weiterhin die Umwelt verschmutzen, kann unser Planet einer schmutzigen Welt werden, ohne frische Luft und sauberes Wasser, aber voll der schrecklichen Krankheiten.

Wir sollten also alles tun, um unserer Umwelt helfen und die Erde zum besten Ort machen, in dem man leben kann.

Heute werden wir dem Müll mehr Aufmerksamkeit widmen und wie mit ihm umgehen. Zunächst schauen wir uns zwei Kurzfilme über das Müllproblem in England und in Deutschland an. Anschließend führen Sie einige Aufgaben aus, die Lösungen für dieses Problem vorschlagen. Um unseren Unterricht zusammenzufassen, macht ihr Plakate und präsentieren sie der Klasse. Sie werden Plakate sowohl auf Englisch als auch auf Deutsch erstellen. So lass uns anfangen!
It's up to you, it's up to me
To live in peaceful beauty.
I want you feel, I want you see,
Remember, it's your duty!

II. Перегляд відеосюжету на тему переробки й утилізації та виконання завдань до нього, додаток 1, https:// www.youtube.com/watch?v=OasbYWF4_S8
I. Watch the film and put the sentences into the correct order according to the video.

1. Children can make the world of difference.

2. The second " $R$ " is for recycling.

3. We can reuse a lot of things again and again.

4. You can take your canvas bags instead of using disposable one.

II. Now let's see how well you've understood the film. Read these statements and say whether they are True or False

1. Reduce, Reuse, Recycle are three magical words because they help us keep our planet clean.

2. It is better to use disposable bags instead of canvas bags when you go to the supermarket.

3. To recycle rubbish we need to use only one big container.

4. The third " $R$ " refers to reduce.

5. We may use a bit of our imagination to reuse a lot of things.

6. Using three "R's" we will make our planet more beautiful.

III. Match the words with their definitions:

\begin{tabular}{|l|l|}
\hline 1. to make less & a) whim \\
\hline 2. pollution & b) reduce \\
\hline 3. to use again & c) disposable \\
\hline 4. using only once and must be thrown away & d) contamination \\
\hline $\begin{array}{l}\text { 5. to use something old to make something } \\
\text { else }\end{array}$ & e) reuse \\
\hline $\begin{array}{l}\text { 6. a sudden wish or idea, especially one that } \\
\text { cannot be reasonably explained }\end{array}$ & f) recycle \\
\hline
\end{tabular}

IV. Fill in the gaps. Use the words from the list.

Imagination; canvas bags; colours; reduce; disposable; recycling stations and containers; reuse; recycling; identify.

The first " $\mathrm{R}$ " is for If you think about it, there are many things you don't need when you go to the supermarket. I'm sure you can take your own instead of using once.

The second " $R$ " is for

Now it is easier than ever. To recycle things we can find places like the

They each have specific to make it easier to

The third " $R$ " refers to How many things do you think we can reuse again and again instead of throwing them away. Let's see. A piece of paper that have only one side printed on, a carton box, a plastic bottle. You think now. Just a little bit of your and I'm sure you can come up with many more exciting and fun new uses for them. Let's make our planet more beautiful and cleaner together.

III. Обговорення результатів виконаних вправ.

We've just watched a video dealing with recycling rubbish. Answer my questions, please. Why should we recycle rubbish? What should we do reduce rubbish? Is it important to reuse it? Why? 
IV. Перегляд відеосюжету (Das Deutschlandlabor, Lektion 11 „Müll“, das Video und Aufgaben zur Lektion 11) про переробку сміття в Німеччині та виконання завдань до них (додаток 2, посилання для виконання завдань https://www.dw.com/de/folge-11-m\%С3\%BCl//l-18869401)

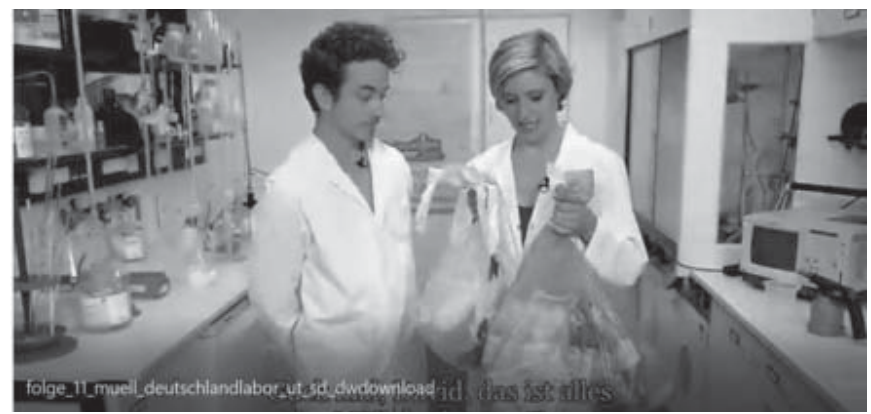

\section{Müll}

In dieser Folge geht es um das Thema „Müll". Welche Wörter kennst du schon? Sieh dir die Bilder an. Welches Wort passt? Ordne zu.
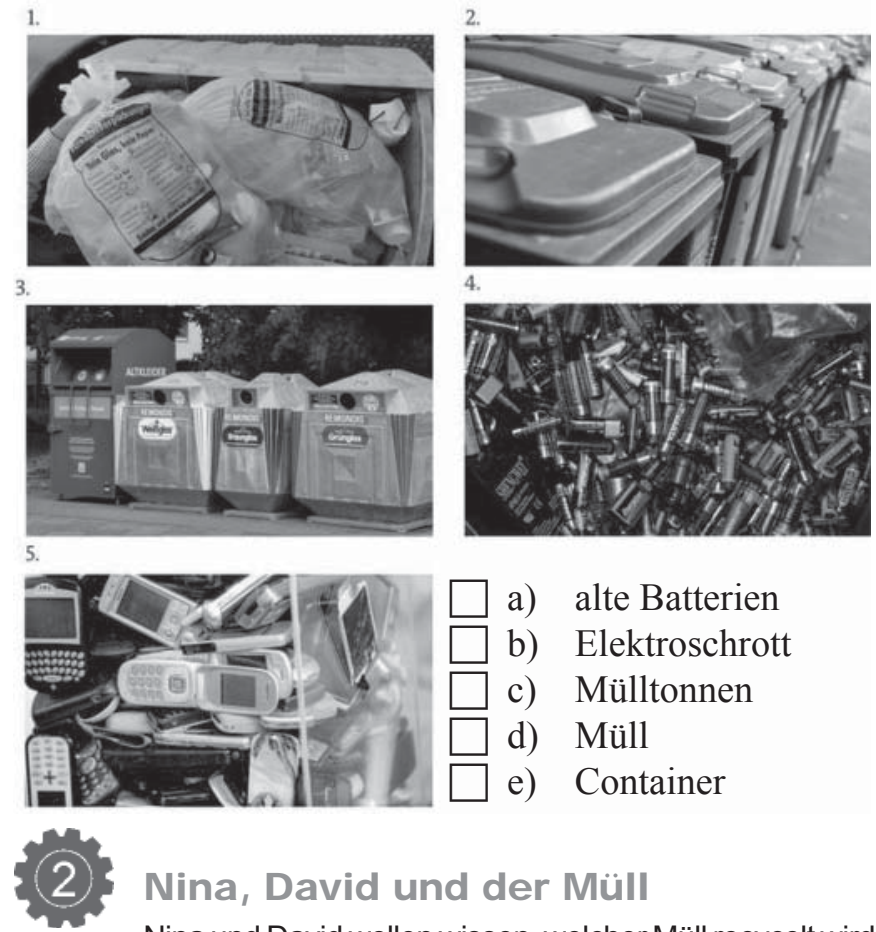
a) alte Batterien
b) Elektroschrott
c) Mülltonnen
d) Müll
e) Container

\section{Nina, David und der Müll}

Nina und David wollen wissen, welcher Müll recycelt wird und wie man Müll vermeiden kann. Sieh dir das Video an. Was passiert in welcher Reihenfolge? Ordner die Zahlen 1 bis $4 \mathrm{zu}$.

a) Nina und David fragen, wie Einkaufen ohne Verpackung funktioniert.

b) Nina und David wollen wissen, wer von den beiden nach dem Einkauf weniger Verpackungen hat.

c) Nina und David fragen, welche Personen ihren Müll trennen.

d) Nina und David fragen, wie viel Müll in Deutschland recycelt wird.

\section{Recycling}

Welcher Müll wird in Deutschland recycelt und wie funktioniert das eigentlich? Sieh dir das Video an und beantworte dann die Fragen. Was ist richtig, was ist falsch? Wähle aus.
1. Jeder Deutsche produziert im $\mid$ ahr etwa $540 \mathrm{~kg}$ Müll.
a) richtig
b) falsch

2. Die meisten Menschen in Deutschland trennen den Müll.
a) richtig
b) falsch

3. Es gibt verschiedene Mülltonnen für unterschiedlichen Müll.
a) richtig
b) falsch

4. Altglas kommt in die Restmülltonne.
a) richtig
b) falsch

5. Elektroschrou gibt man auf einem Wertstoffhof ab.
a) richtig
b) falsch

6. In Deutschland wird 80 Prozent des Mülls wiederverwertet.
a) richtig $\square$
b) falsch

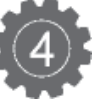

\section{Wie trennt und vermeidet man in Deutschland Müll?}

In den vorangehenden Übungen hast du viel über das Thema „Müll" erfahren. Hier kannst du dein Wissen noch einmal überprüfen. Sieh dir das Video noch einmal an. Was stimmt? Mehrere Antworten sind richtig.

1. Welche Mülltonnen gibt es normalerweise Tür jedes Haus?
$\square$ a) Biomüll
$\square$ c) Resfmüll
b) Glas
d) Verpackung

2. Was sammeln die befragten Personen, außer dem Hausmüll, noch?
a) Pflanzen
b) Metall
c) Elcktromüll
d) Batterien

3. Welche Informationen bekommen Nina und David auf dem Recydinghof?

a) Nur das Papier kann recycelt werden.

$\square$ b) Mehr als SOProzent des Elektroschrotis wird wiederverwertet.

c) Davids Fahrrad kann nicht recycelt werden.

d) Kartons werden aus Altpapier hergestellt.

4. Nina und David möchten beim Einkaufen Müll vermeiden. Was ist richtig?

$\square$ a) Nina und David bekommen eine Plastiktüte für ihren Einkauf.

$\square$ h) Im Biosupermarkt kann man das Obst ohne Verpackung kaufen,

c) Trockenobst kann man im Biomarkt im Video in selbst mitgebrachte Gefäße füllen.

$\square$ d) Der Käse wi rd in Papier verpackt.

\section{Wortschatz zum Thema „Müll"}

Findest du für jedes Wort die richtige Definition? Lies die Definitionen und ordne die Ergänzungen zu. 


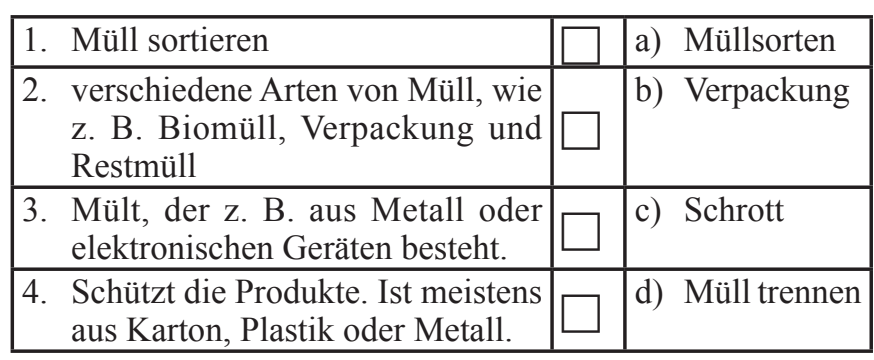

\section{Mülltrennung in Deutschland}

Fasse wichtige Informationen zur Mülltrennung zusammen. Lies den Text. Was passt in die Lücken? Ordne zu.

Farben / Wertstoflhof / Verpackung / trennen / Glas /

Gefäße / Papiertüte / Mülltonnen / verbrannt

In Deutschland_______ viele Menschen den Müll. In jedem

Haus gibt es deshalb verschiedene Sie haben

unterschiedliche Man darf aber nicht alles in die Mülltonnen werfen. Deshalb soll man zum Container und Sondermüll aufden

Etwa 10 Prozent des Mülls wird

bringen. viel Müll entsteht, kann man in manchen Biosupermärkten Lebensmittel ohne kaufen. Dazu müssen die Kunden eigene mitbringen oder sie bekommen eine

V. Match English words with their German equivalents / Ordnet Englische Wörter mit den deutschen EquivaIenten zu.

\begin{tabular}{|l|l|}
\hline 1. Earth & a) die Laune \\
2. waste & b) reduzieren \\
3. plastic & c) die Welt verändern \\
4. disposable & d) Recyclen \\
5. contamination & e) die Erde \\
6. whim & f) wiederverwenden \\
7. reduce & g) das Plastik \\
8. reuse & h) Wegwerf- \\
9. recycle & i) die Verschmutzung \\
10. world of difference & j) der Müll/Abfälle \\
\hline
\end{tabular}

VI. Now, the most creative part of our meeting. You are going to work in groups. The task is to make up posters on the problem of recycling rubbish in the UK and Germany. Use the vocabulary you've already learnt. (Students do this task accompanied by "The Earth Song"). (додаток 3, https://www.youtube.com/watch?v=XAi3VTSd TxU\&list=PLitLzrkcD7RGDrzXPHmAGJig3JxSsM2Ny\&ind ex=2\&t=0s). Arbeitet inr in den Gruppen und macht Plakate zum Problem des Müllrecyclings in Großbritannien und in Deutschland. Verwendet ihr die Wörter, die ihr in dieser Stunde gelernt habt. (Die Schüler erledigen diese Aufgabe mit der Begleitung von „Earth Song“ Lied).

VII. Представлення виконаної роботи спікером від кожної групи англійською або німецькою мовою (на вибір).

\section{Summing up.}

Thank you very much for your informative posters. You're really creative and clever students. You've worked very hard today and coped with the tasks successfully. Now, we are sure that our planet is the right and safe hands. Zusammenfassung. Vielen Dank für eure informativen Poster. Ihr seid wirklich kreative und kluge Schüler. Ihr habt heute sehr gut gearbeitet und erfolgreich mit den Aufgaben geschafft. Jetzt sind wir sicher, dass unser Planet in den richtigen und sicheren Händen ist.

\section{КЛЮЧІ ДО ЗАВДАНЬ}

Task I. 1-4, 2-2, 3-3, 4-1. Task II. 1-T, 2-F, 3-F, 4-F, 5-T, 6-T. Task III. 1-b, 2-d, 3-e, 4-c, 5-f, 6-a. Task IV. The first "R" is for reduce . If you think about it, there are many things you don't need when you go to the supermarket. I'm sure you can take your own canvas bag instead of using disposable once. The second " $R$ " is for recycling. Now it is easier than ever. To recycle things we can find places like the recycling stations and containers. They each have specific colours to make it easier to identify. The third "R" refers to reuse. How many things do you think we can reuse again and again instead of throwing them away. Let's see. A piece of paper that have only one side printed on, a carton box, a plastic bottle. You think now. Just a little bit of your imagination and I'm sure you can come up with many more exciting and fun new uses for them. Let's make our planet more beautiful and cleaner together. Task V. Lösungen zu den Übungen zum Thema „Müll“.

Übung 1. Müll. 1-d, 2-c, 3-e, 4-a, 5-b. Übung 2. Nina, David und der Müll. 1-c, 2-d, 3-b, 4-a. Übung 3. Recycling. 1-b, 2-a, 3-a, 4-b, 5-a, 6-a. Übung 4. Wie trennt und vermeidet man in Deutschland Müll? 1-a,c,d. 2-d. 3-b,d. 4-b,c,d. Übung 5. Wortschatz zum Thema „Müll“. 1-d, 2-a, 3-c, 4-b. Übung 6. Mülltrennung in Deutschland. In Deutschland trennen viele Menschen den Müll. In jedem Haus gibt es deshalb verschiedene Mülltonnen. Sie haben unterschiedliche Farben. Man darf aber nicht alles in die Mülltonnen werfen. Deshalb soll man Glas zum Container und Sondermüll auf den Wertstoffhof bringen. Etwa 10 Prozent des Mülls wird verbrannt. Damit nicht so viel Müll entsteht, kann man in manchen Biosupermärkten Lebensmittel ohne Verpackung kaufen. Dazu müssen die Kunden eigene Gefäße mitbringen oder sie bekommen eine Papiertüte. Task VI. 1-e, 2-j, 3-g, 4-h, 5-i, 6-a, 7-b, 8-f, 9-d, 10-c.

\section{ДОДАТКИ}

Завдання до уроку, аудіо- та відеоматеріали доступні за посиланнями:

1. https://www.youtube.com/watch?v=OasbYWF4_S8 ("Reuse, Recycle, Reduce").

2. https://www.dw.com/de/folge-11-m\%C3\%BCII/l-18869401 (Das Deutschlandlabor, Lektion 11 „Mül““, das Video und Aufgaben zur Lektion 11).

3. https://www.youtube.com/watch? $v=X A i 3 V T S d T x U \& l i s t=P L i t L z r k c D 7$ RGDrzXPHmAGJig3JxSsM2Ny\&index=2\&t=0s (,The Earth Song“)

\section{СПИСОК ПОСИЛАНЬ}

Антонов Н. С. Інтеграційна функція навчання / Н. С. Антонов. - К.: Освіта, 1989. - 304 с.

Базиль С. М. Бінарне заняття з дисциплін «Маркетинг» і «Інформатика та комп'ютерна техніка» [Електронний ресурс] / С. М. Базиль // Режим доступу: http://www.teacherjournal.com. ua/proftexosvta/9024-bnarnezanyattya-z-disczipln-ImarketingrInformatika-ta-kompyuternatexnkar.html.

Ковальчук М. Бінарний урок: одна з форм інтерактивних технологій навчання / М. Ковальчук, Т. Постовалова // Освіта. Технікуми. Коледжі. - 2009. - № 2. - С. 19-24.

Козловська І. М. Теоретико-методологічні аспекти інтеграції знань учнів професійно-технічної школи: дидактичні основи : монографія / За ред. С. У. Гончаренка. - Львів : Світ, 1999. - 302 с.

Красик О. Ю. Бінарні заняття [Електронний ресурс] / О. Ю. Красик. - Режим доступу: oles.at.ua/statti/binarni uroki.doc.

Методика викладання іноземних мов у середніх навчальних закладах: Підручник. Вид. 2-е, випр. і перероб./Кол. авторів під керівн. С.Ю. Ніколаєвої. - К.: Ленвіт, 2002. - 328 с.

Пінчук Г. Г. Інтеграція навчального процесу як чинник розвитку пізнавальної активності учнів [Електронний ресурс] / Г. Г. Пінчук, О. В. Титар. - Режим доступу: http://osvita.ua/school/lessons.

\section{IHTEPHET-PECYPCИ}

1. https://osvita.ua/school/lessons summary/edu technology/49270/

2. https://vseosvita.ua/library/binarnij-urok-ak-forma-integrovanogonavcanna-83362.html

3. https://vseosvita.ua/library/tema-integrovanij-urok-slah-do-cilisnogo-sprijnatta-ucnami-navkolisnogo-svitu-79033.html

4. https://www.slideshare.net/anastasiaborisovna/ss-68489665

Отримано 9.11.20 